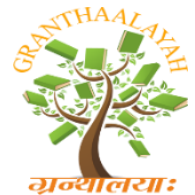

\author{
INTERNATIONAL JOURNAL OF RE
GRANTHAALAYAH \\ A knowledge Repository
}

Science

\title{
WEEDS DIVERSITY AND ITS IMPACT ON THE EXISTENCE OF MAIN PESTS AND DISEASES IN THEOBROMA CACAO IN TABANAN DISTRICT, BALI PROVINCE INDONESIA
}

\author{
I Ketut Widnyana ${ }^{1}$, Ni Gst. Ag. Gde EkaMartiningsih ${ }^{\mathbf{1}}$, I Made Suryana ${ }^{\mathbf{1}}$, Cokorda \\ Javandira $^{1}$, Ni Nyoman Yudiarini ${ }^{1}$ \\ ${ }^{1}$ Lecturer at the Faculty of Agriculture, Mahasaraswati Denpasar University
}

\begin{abstract}
Cocoa is one of the plantation commodities which in the last decade has become a source of income for Balinese farmers. However, the current condition of farmers' income from cocoa cultivation has decreased due to several factors including weeds, pest and diseases. This study aims to determine the type and dominance of weeds on cocoa plantations, their impact on cocoa main pests and diseases. The research was carried out by the observation method, namely direct observation of the farmers' cocoa gardens. Weed samples were calculated using the quadratic method, observing the attack of pests was determined by diagonal methods before and after the maintenance of cocoa plants. The results of the study found that there were 10 species of weeds that disrupted cocoa plants in Tabanan regency namely, Cyperusrotundus L, Imperatacylindrica L, Arachniodesaristata (G. Forst) Tindale, Brachiariamutica, Colocasia esculenta L Schott, Crassocephalumcrepidioides, Axonopuscompressus (Swartz) Beauv, Mikania micrantha Kunt, Ageratum conyzoides L, Synedrellanodiflora L. The highest density was found in the $S$. nodiflora L. type which was 5.73 units / $\mathrm{m} 2$, followed by $A$. conyzoides L. 4.86 units / $\mathrm{m} 2$, and $C$. crepidioideswhich was 4.0 units / $\mathrm{m} 2$. The lowest density is found in I. cylindrica L which is 0.86 units / $\mathrm{m} 2$. The poorly maintained cocoa plantations, only $30.14 \%$ of the potential results that should have been obtained, $31.37 \%$ were damaged by Phytophthora palmivora, $21.16 \%$ damaged by Helopeltis sp. and $17.33 \%$ were damaged by Conophomorpacramerella. Technical improvement in cultivation canincrease potential the results by $62.86 \%$ of total cocoa production. Besides that, there was a decrease in the attack of P. palmivora to only $7.84 \%$, Helopeltis sp. $5.70 \%$ and C. cramerella $12.5 \%$.
\end{abstract}

Keywords: Cocoa; Weeds; Density; Pest; Diseases.

Cite This Article: I Ketut Widnyana, Ni Gst. Ag. Gde EkaMartiningsih, I Made Suryana, Cokorda Javandira, and Ni Nyoman Yudiarini. (2019). "WEEDS DIVERSITY AND ITS IMPACT ON THE EXISTENCE OF MAIN PESTS AND DISEASES IN THEOBROMA CACAO IN TABANAN DISTRICT, BALI PROVINCE INDONESIA." International Journal of Research Granthaalayah, 7(10), 371-379. https://doi.org/10.29121/granthaalayah.v7.i10.2019.407. 


\section{Introduction}

Indonesia has many islands with very potential land for cocoa cultivation. Cocoa as one of the plantation crops, is one of the plantation commodities which has a very important export value in increasing the country's foreign exchange. Since 1980 the Indonesian government has given priority to developing cocoa plants as one of the leading commodities (Susanto, 2010). At present Indonesia is the third major producer of cocoa after Ghana and République de Côte d'Ivoire. The area of cocoa plants in Indonesia is $1,774,303.97$ ha (in 2014) with a production of 777,500 tons and around $90 \%$ cultivated by the people (Indonesian plantation statistics, 2017). But according to Hafsa et all. (2015), cocoa productivity in Indonesia is still low, only reaching $200 \mathrm{~kg} / \mathrm{ha} / \mathrm{year}$, still far below the actual potential reaching 2 tons ha / year. One of the causes of low cocoa production in Indonesia is the attack of pests, diseases and weeds. Weeds can reduce yield on cocoa plants by $12-80 \%$ so it is very important to control (Yulianita, 2016).According to Suhendi (2007) several factors that cause low productivity of cocoa in Indonesia in addition to pest attacks and weed disturbances, are climate anomalies, damaged plant canopy, reduced plant population, improper cultivation technology, use of non-quality varieties, and most plants that have been old so it's less productive. Most of the age of cocoa plants in Bali is more than 10 years.

One effort that can be done to improve the quality and quantity of cocoa production is by paying attention to the cultivation techniques including good soil processing, adequate and routine fertilization, continuous weed control, pest and disease control, and the provision of growth regulators, and provision superior cocoa seeds (Purbaet all. 2014). At this time the presence of weeds in cocoa cultivation is an important problem, for that it is necessary to control it in order to obtain satisfactory cocoa production. Success in weed control is based on good knowledge of the biological properties of weeds (Sukman and Yakub, 2002).

Weeds have a negative effect on plant growth and production so that all means are attempted to control them. The effect of weeds is very visible in young plants which are a critical period of plants. In this critical period, weed control efforts must be carried out more intensively by taking into account the economic threshold factor. Weed control is primarily aimed at suppressing weed growth to the extent that tolerance is economically detrimental (Barus, 2003). In general weeds found in cocoa plantations are; a) grass group: Imperatacylindrica L, Axonopuscompressus Swartz Beauv, Otacholaconjugatum, Iscpalumtimorense, Setariaplicata; b) group of puzzles: Cyperusrotundus L, Cyperuskyllingia; c) broad leaf group: Mikania micranthaKunt, and Alhenatherabrasiliana (Yulianita, 2016).

Efforts to increase the productivity of cocoa plants are very necessary. The results of the observation showed that most of the cocoa plantations in the Tabanan district were not well maintained. Various types of weeds grow in the area of cocoa cultivation, competing with cocoa plants which cause a decrease in cocoa productivity. Besides that, weeds growing in cocoa cultivation areas facilitate the transfer of various pests and diseases that have the potential to damage cocoa plants. This study was conducted to obtain information about the types of weeds and how it impacts on pests and major diseases on cocoa cultivation in Tabanan regency, Bali province Indonesia 


\section{Material and Methods}

The location of the study was in the cocoa gardens in Tabanan Regency, Bali Province - Indonesia, which were held from November 2017 to May 2018. The research was conducted using survey methods by conducting direct observations on 5 (five) locations of cocoa gardens that represented each data districts. Data collection was carried out directly in the field using the method of vegetation analysis and quadratic method by observing sample plots in the field. Weed samples were taken by placing a $1 \mathrm{~m} \times 1 \mathrm{~m}$ squared plot five times on each selected area in the cocoa planting area. Each weed species found in the square plot is identified by type and species, then counted.

Observation of major pest and disease attacks is carried out by taking 15 samples of productive cocoa trees diagonally in the garden, this is done before cocoa maintenance and 6 months after good maintenance.

In plot observations, the variables observed were the number of each type of weed in the plot and the dominant type of weed that grew in the plot. Data obtained from the plot results are used to calculate Density (D), Relative Density (RD), and Frequency (F) of Relative Frequency (RF), (Odum, 1993) using the formula as follows:

\section{a. Density (D)}

Density is the number of individuals of a species at a particular location. The formula is as follows.

$$
\text { Density }=\frac{\text { The number of individual species in the sample subplot }}{\text { Total number of sample area }}
$$

\section{b. Relative Density (RD)}

Relative density is the ratio of the density of certain weed types to the total density of all types. The formula is as follows.

$$
\text { Relative Density }=\frac{\text { Specific species density }}{\text { Total density of all species }} \text { X 100\% }
$$

\section{c. Frequency $(\mathbf{F})$}

Frequency is the ratio of the number of sample plots with certain types of weeds to the sample plots made, the formula is as follows.

Frequency $=\frac{\text { Subplot numbers are overgrown with certain species }}{\text { Number of example subplots }}$




\section{d. Relative Frequency (RF)}

Relative frequency is frequency ratio of the weed type to the number of frequencies of all types. The formula is as follows.

$$
\text { Relative Frequency }=\frac{\text { Frequency of certain species }}{\text { Number of example subplots }} \quad X 100 \%
$$

\section{Results and Discussion}

Based on research that has been carried out in 5 study locations, there are 6 weed families in the cocoa plantation area in Tabanan Regency, namely Asteraceae, Araceae, Cyperaceae, Dryopteridaceae, Graminales, and Poaceae (Table 1). Of the 6 weed families, the most species were found in the Familia Asteraceae as many as 4 species, and the Poaceae were 2 species, while the other families were only 1 species.

Table 1: Family and types of weeds in the cocoa plantations of the Tabananregency, Bali

\begin{tabular}{|c|c|c|c|c|c|}
\hline No & Family & Qty & Species & Indonesian name & Amount \\
\hline 1 & Asteraceae & 4 & $\begin{array}{l}\text { Crassocephalumcrepidioides, } \\
\text { Mikania micranthakunt, } \\
\text { Ageratum conyzoides L, } \\
\text { Synedrellanodiflora } \mathrm{L}\end{array}$ & $\begin{array}{l}\text { Junggul } \\
\text { Sembungrambat } \\
\text { Bandotan } \\
\text { Jotangkuda }\end{array}$ & $\begin{array}{l}225 \\
65 \\
247 \\
331\end{array}$ \\
\hline 2 & Araceae & 1 & Colocasia esculenta $(\mathrm{L})$ Schott & Talas & 39 \\
\hline 3 & Cyperaceae & 1 & Cyperusrontundus $\mathrm{L}$ & Teki-tekian & 69 \\
\hline 4 & Dryopteridaceae & 1 & Arachniodesaristata & Pakis & 137 \\
\hline 5 & Graminales & 1 & Brachiariamutica (Forsk) Stapf & Malela & 52 \\
\hline 6 & Poaceae & 2 & $\begin{array}{l}\text { Imperatacylindrica }(\mathrm{L}) \\
\text { Axonopuscompressus (Swartz) } \\
\text { Beauv }\end{array}$ & $\begin{array}{l}\text { Alang - alang } \\
\text { JakutPait }\end{array}$ & $\begin{array}{l}36 \\
66\end{array}$ \\
\hline
\end{tabular}

When viewed from the average number of each species that grows in the cocoa plantation area, the most is the S.nodiflora L. species, which is 331 units $(26.12 \%)$, followed by A.conyzoides $\mathrm{L}$. 247 units (19.49\%), and C.crepidioides 225 (17.76\%). While the fewest species are I.cylindrica L. as many as 36 units $(02.84 \%)$ (Table 2$)$

Table 2: The number of plots overgrown with certain types of weeds in cocoa plantations in Tabanan regency, Bali

\begin{tabular}{|l|l|l|l|l|}
\hline No & \multicolumn{1}{|c|}{ Weed type } & \multicolumn{1}{|c|}{$\begin{array}{c}\text { Number of } \\
\text { observation plots }\end{array}$} & $\begin{array}{c}\text { Total } \\
\text { weed }\end{array}$ & $\begin{array}{l}\text { Percentage of weed } \\
\text { types (\%) }\end{array}$ \\
\hline 1 & SynedrellanodifloraL & 13 & 331 & 26.12 \\
\hline 2 & Ageratum conyzoides $\mathrm{L}$ & 11 & 247 & 19.49 \\
\hline 3 & Crassocephalumcrepidioides & 9 & 225 & 17.76 \\
\hline
\end{tabular}




\begin{tabular}{|l|l|l|l|l|}
\hline 4 & $\begin{array}{l}\text { Arachniodesaristata(G.Forst) } \\
\text { tindale }\end{array}$ & 7 & 137 & 10.81 \\
\hline 5 & CyperusrotundusL & 6 & 69 & 05.44 \\
\hline 6 & $\begin{array}{l}\text { Axonopuscompressus(Swartz) } \\
\text { Beauv }\end{array}$ & 5 & 66 & 05.21 \\
\hline 7 & Mikania micranthaKunt & 4 & 65 & 05.13 \\
\hline 8 & Brachiariamutica & 3 & 52 & 04.10 \\
\hline 9 & Colocasia esculenta L Schott & 2 & 39 & 03.08 \\
\hline 10 & ImperatacylindricaL & 2 & 36 & 02.84 \\
\hline & TOTAL & $\mathbf{6 2}$ & $\mathbf{1 . 2 6 7}$ & $\mathbf{1 0 0}$ \\
\hline
\end{tabular}

Based on the results of density analysis which is the number of individual weed species at a particular location, the highest density was found in the S.nodiflora L. type which was 5.73 units / $\mathrm{m} 2$, followed by A.conyzoides L. 4.86 units / $\mathrm{m} 2$, and C.crepidioides which was 4.0 units / m2. The lowest density is found in I.cylindrica L which is 0.86 units / $\mathrm{m} 2$. (Table 3). Based on the relative density value which is a density ratio of certain weed species with total density of all types, the density value of the S.nodiflora L .weed was $24.34 \%$, followed by A.conyzoides L. which was $19.97 \%$, and C.crepidioides $18.19 \%$. while the lowest density is found in I.cylindrica $\mathrm{L}$ which is 2.91\%. (Table 3)

Table.3: The density of weed species found in the cocoa plantations in Tabanan regency, Bali

\begin{tabular}{|c|c|c|c|c|}
\hline No & Weed type & Population & Density (units $/ \mathbf{m}^{2}$ ) & Relative Density (\%) \\
\hline 1 & Synedrellanodiflora $\mathrm{L}$ & 331 & 5.73 & 24.34 \\
\hline 2 & Ageratum conyzoides $\mathrm{L}$ & 247 & 4.86 & 19.97 \\
\hline 3 & Crassocephalumcrepidioides & 225 & 4.00 & 18.19 \\
\hline 4 & $\begin{array}{l}\text { Arachniodesaristata(G.Forst) } \\
\text { tindale }\end{array}$ & 137 & 3.06 & 11.70 \\
\hline 5 & Cyperusrotundus $\mathrm{L}$ & 69 & 2.66 & 5.58 \\
\hline 6 & $\begin{array}{l}\text { Axonopuscompressus (Swartz } \\
\text { ) Beauv }\end{array}$ & 66 & 2.20 & 5.34 \\
\hline 7 & Mikania micranthaKunt & 65 & 1.73 & 5.25 \\
\hline 8 & Brachiariamutica & 52 & 1.33 & 4.21 \\
\hline 9 & Colocasia esculenta L Schott & 39 & 0.86 & 3.15 \\
\hline 10 & Imperatacylindrica $\mathrm{L}$ & 36 & 0.86 & 2.91 \\
\hline \multicolumn{2}{|c|}{ TOTAL } & 1267 & 82.47 & 27.29 \\
\hline
\end{tabular}

Analysis of the frequency based on the appearance of weed species in the sample plot compared with the sample plots made, the results of the frequency analysis showed that the highest frequency of occurrence was found in S.nodiflora L. weed, which was 0.86 with a relative frequency of $5.73 \%$, followed by A.conyzoides L. for 0.73 with a relative frequency of $4.86 \%$, and C.crepidioides of 0.6 with a relative frequency of $4.0 \%$. the rare occurrence of weed species is I.cylindrica $\mathrm{L}$.with a frequency of 0.13 and a relative frequency of $0.86 \%$ (Table 4). 
Table 4: Frequency and Relative Frequency of weeds found in cocoa plantations in Tabananregency, Bali

\begin{tabular}{|l|l|c|c|c|}
\hline NO & \multicolumn{1}{|c|}{ Nama Species } & Amount & Frequency & Relative Frequency (\%) \\
\hline 1 & SynedrellanodifloraL & 331 & 0.86 & 5.73 \\
\hline 2 & Ageratum conyzoides $\mathrm{L}$ & 247 & 0.73 & 4.86 \\
\hline 3 & Crassocephalumcrepidioides & 225 & 0.60 & 4.00 \\
\hline 4 & $\begin{array}{l}\text { Arachniodesaristata(G.Forst) } \\
\text { tindale }\end{array}$ & 137 & 0.46 & 3.06 \\
\hline 5 & Cyperusrotundus L & 69 & 0.40 & 2.66 \\
\hline 6 & $\begin{array}{l}\text { Axonopuscompressus(Swartz) } \\
\text { Beauv }\end{array}$ & 66 & 0.33 & 2.20 \\
\hline 7 & Mikania micranthaKunt & 65 & 0.26 & 1.73 \\
\hline 8 & Brachiariamutica & 52 & 0.20 & 1.33 \\
\hline 9 & Colocasia esculenta L Schott & 39 & 0.13 & 0.86 \\
\hline 10 & Imperatacylindrica $\mathrm{L}$ & 36 & 0.13 & 0.86 \\
\hline \multicolumn{2}{|l|}{ TOTAL } & 1267 & 1 & 27.29 \\
\hline
\end{tabular}

Table 3 shows high weed density and weed diversity data; this means that farmers do not control weed populations well so that cocoa gardens are not maintained. this condition has an impact on cocoa productivity which is very low at only $100-200 \mathrm{~kg} /$ hectare / month. This production is certainly very low compared to cocoa cultivation which can produce at least $1000 \mathrm{~kg}$ of dry cocoa / ha / month. This low cocoa productivity causes many farmers in Tabanan district to switch to other cultivated crops such as coffee, banana, paddy rice or other crops, without trying to improve the techniques of cocoa cultivation properly. The presence of weeds in cocoa gardens is very influential not only on young cocoa plants but also old cocoa. In young cocoa weed control must be carried out more intensively by taking into account economic threshold factors, because this phase is a critical period of cocoa. But weed control must also be done on cocoa that is already productive. Accordance with the opinion of Sembodo (2010), that's weeds can cause a slow loss while interacting with cocoa plants. These losses occur through the process of competition between weeds and plants in obtaining growth factors such as nutrients, water, light, $\mathrm{CO} 2$, and growing space. In addition to competition, losses can also occur through the allelopathy process, namely the process of suppressing growth due to chemical compounds (allelochemistry) released by weeds.

The presence of weeds in the cocoa cultivation area is not only detrimental because of the competition of soil nutrients and allelopathic compounds that suppress cocoa growth, but more important than that is the presence of weeds to be suitable habitat for several types of cocoa pests and diseases. This is evidenced by the results of observations in the field which showed that there were pests and diseases in cocoa farms, namely cocoa fruit borer Conophomorpacramerella, fruit sucking pest Helopeltisantonii, and cocoa fruit rot caused by Phytoptorapalmivora, three pests and diseases it is a major disruption to cocoa cultivation in Bali. Even in one cacao tree, there can be a third disturbance from the pest. Tables 5 and 6 show the attacks of the three main cocoa pests and diseases in well maintained compared to the poorly maintained cocoa gardens. 
Table 5: Percentage of cocoa fruits attacked by P. palmivora, Helopeltissp, and C. cramerella in poorly maintained cocoa gardens.

\begin{tabular}{|c|c|c|c|c|c|c|c|c|c|}
\hline \multirow[t]{2}{*}{$\begin{array}{c}\text { Field of } \\
\text { observation }\end{array}$} & \multicolumn{2}{|c|}{$\begin{array}{c}\text { Healthy } \\
\text { cocoa fruits }\end{array}$} & \multicolumn{2}{|c|}{$\begin{array}{c}P . \\
\text { palmivoraattack }\end{array}$} & \multicolumn{2}{|c|}{$\begin{array}{c}\text { Helopeltis sp. } \\
\text { attack }\end{array}$} & \multicolumn{2}{|c|}{$\begin{array}{c}C . \\
\text { cramerellaattack }\end{array}$} & \multirow[t]{2}{*}{$\begin{array}{c}\text { Number of } \\
\text { samples }\end{array}$} \\
\hline & units & $\%$ & units & $\%$ & units & $\%$ & units & $\%$ & \\
\hline Field 1 & 54 & 27.55 & 66 & 33.67 & 44 & 22.45 & 32 & 16.33 & 196 \\
\hline Field 2 & 62 & 32.80 & 70 & 37.04 & 34 & 17.99 & 23 & 12.17 & 189 \\
\hline Field 3 & 46 & 25.99 & 48 & 27.12 & 41 & 23.16 & 42 & 23.73 & 177 \\
\hline Field 4 & 52 & 34.21 & 42 & 27.63 & 32 & 21.05 & 26 & 17.11 & 152 \\
\hline Average & \multicolumn{2}{|c|}{30.14} & \multicolumn{2}{|c|}{31.37} & \multicolumn{2}{|c|}{21.16} & \multicolumn{2}{|c|}{17.33} & 714 \\
\hline
\end{tabular}

Table 5 shows that in the poorly maintained cocoa plantations, only $30.14 \%$ of the potential results that should have been obtained, $31.37 \%$ were damaged by fruit rot by $P$. palmivora, $21.16 \%$ damaged due to Helopeltis sp. and $17.33 \%$ were damaged by the attack of C. cramerella stem borer.According to Subiantoro (2009) borer cocoa pod C. cramerella can produce up to $80 \%$. Helopeltissp, attacks young fruit and shoots. The attack on the young fruit causes the fruit to die, while the old fruit causes an abnormal fruit shape. The attack on fruit can reduce the yield of $42 \%$ (Wardoyo, 1988). While severe attacks on shoots can reduce cocoa production by 36-75\% (Edi. 2015). The percentage of fruit rot disease caused by $P$. palmivora fungi in untreated gardens can reach $60.4 \%$ (Defitri, 2017).

Through education and training to farmer groups for 6 months in good cocoa cultivation techniques, such as weed control, unproductive pruning, fertilizing with organic fertilizers provides encouraging results, as presented in Table 6, which shows that technical improvement in cultivation can increase potential the results can reach $62.86 \%$ of total cocoa production. Besides that, there was a decrease in the attack of P. palmivora to only $7.84 \%$, Helopeltis $s p .5 .70 \%$ and C. cramerella $12.5 \%$. If the maintenance of cocoa plantations is carried out continuously, it can reduce the attack of the three main cacao pests and diseases. This is in accordance with Defitri's opinion (2017) that in the garden which was carried out intensive maintenance of fruit rotten disease, it was $7.32 \%$.

Table 6: Percentage of cocoa fruits attacked by P. palmivora, Helopeltissp, and C. cramerella in well-maintained cocoa gardens.

\begin{tabular}{|c|c|c|c|c|c|c|c|c|c|}
\hline \multirow[t]{2}{*}{$\begin{array}{c}\text { Field of } \\
\text { observation }\end{array}$} & \multicolumn{2}{|c|}{$\begin{array}{c}\text { Healthy } \\
\text { cocoa fruits }\end{array}$} & \multicolumn{2}{|c|}{$\begin{array}{c}P . \\
\text { palmivoraattack }\end{array}$} & \multicolumn{2}{|c|}{$\begin{array}{l}\text { Helopeltis } \\
\text { sp. attack }\end{array}$} & \multicolumn{2}{|c|}{$\begin{array}{c}C . \\
\text { cramerellaattack }\end{array}$} & \multirow{2}{*}{$\begin{array}{c}\text { Number } \\
\text { of } \\
\text { samples }\end{array}$} \\
\hline & units & $\%$ & units & $\%$ & units & $\%$ & units & $\%$ & \\
\hline Field 1 & 68 & 60.18 & 10 & 8.85 & 3 & 2.65 & 32 & 14.00 & 113 \\
\hline Field 2 & 80 & 68.38 & 8 & 6.84 & 6 & 5.13 & 23 & 13.00 & 117 \\
\hline Field 3 & 82 & 55.78 & 14 & 9.52 & 9 & 6.12 & 42 & 10.00 & 147 \\
\hline Field 4 & 98 & 67.12 & 9 & 6.16 & 13 & 8.90 & 26 & 13.00 & 146 \\
\hline Average & & 62.86 & & 7.84 & & 5.70 & & 12.50 & 523 \\
\hline
\end{tabular}

Several weed control methods have been carried out on cocoa farms, both manual, mechanical, cultivation, biological, and chemical methods using herbicides, but many farmers combine several methods at the same time to provide better results. The most widely used method is the chemical 
method using herbicides. This method is considered more practical and beneficial compared to other methods, because it requires less labor and relatively shorter implementation time. However, the use of herbicides needs to be accompanied by specific knowledge and skills for farmers such as the introduction of dominant types of weeds, the level of influence on plants, alternative ways of control that need to be done, introduction of types of herbicides, equipment, application techniques, and environmental safety and security factors. The herbicides used must be selective and harmless to humans, animals and the environment.

\section{Conclusion}

From the results of the study it can be concluded that:

1. The types and species of weeds found in cocoa plantations in Tabanan Regency consist of 10 species, namely C.rotundus L., I.cylindrica L., A.aristata (G.Forst) Tindale, B.mutica, C.esculenta L.Schott, C.crepidioides, A.compressus (Swartz) Beauv, M.micrantha Kunt, A.conyzoides L., S.nodiflora L.

2. The highest weeds density was found in the S.nodiflora L. type which was 5.73 units / m2, followed by A.conyzoides L. 4.86 units / $\mathrm{m} 2$, and C.crepidioides which was 4.0 units / m2. The lowest densityis found in I.cylindrica L which is 0.86 units / $\mathrm{m} 2$

3. The poorly maintained cocoa plantations, only $30.14 \%$ of the potential results that should have been obtained, $31.37 \%$ were damaged by fruit rot by $P$. palmivora, $21.16 \%$ damaged by Helopeltissp. and $17.33 \%$ were damaged by C. cramerella stemborer.

4. Technical improvement in cultivation can increase potential the results can reach $62.86 \%$ of total cocoa production. Besides that, there was a decrease in the attack of $P$. palmivora to only $7.84 \%$, Helopeltissp. $5.70 \%$ and C. cramerella $12.5 \%$.

\section{Acknowledgement}

Thank you to the parties who donated the research that has been done, namely the PBCRC (Plant Biosecurity Cooperative Research Center) and the Leader of Mahasaraswati Denpasar University

\section{References}

[1] Barus, E. 2003. Weed Control in Plantation. Kanisius Publisher. Yogyakarta (in Bahasa).

[2] Defitri, Y. 2017. Fruit rot of cocoa plants (Theobroma cacao L.) and percentage of attacks in Betung village, KumpehIlir sub-district, Muaro Jambi district. Jurnal Media Pertanian. 2/2: $98-103$ ISSN online 2581 - 1606 (in Bahasa)

[3] Hafsa, S., Zuyasnadan Firdaus. 2015. Screening of coco genotypes resistant to fruit diseases (Phythophthrapalmivora) in Aceh Besar. Jurnal Floratek. 10: 79 - 86. (in Bahasa)

[4] Edi, P. 2015. Pests and Diseases of the cacao plant (Theobroma cacao L.). Forestry Extension Bantul Regency. 3/3: 7 - 10. (in Bahasa)

[5] Odum, E.P. 1994. Basics of Ecology. Third Edition. Gadjah Mada University Press, Yogyakarta (Tjahjono Samingar Translator).

[6] Purba, ID. Irsal, J. Ginting. 2014. Response of Cacao (Theobroma cacao L.) Seedlings Vegetative Growth with the Provision of Vermicompost and Water at Various Field Capacity. Jurnal Online Agroekoteknologi . 2/2 : 561- 576. ISSN No. 2337- 6597 
[7] Raharjo. 1999. Cocoa and Cultivation, and its economic aspects. Yogyakarta: Kanisius Publisher (in Bahasa)

[8] Sembodo, D.R.J. 2010. Weed and Management. Grahallmu Publishers. Yogyakarta. (in Bahasa).

[9] Indonesian Plantation Statistics, 2017. 2015-2017 Cocoa Commodities. Directorate General of Plantation / Directorate General of Estate Crops. (in Bahasa).

[10] Subiantoro, R. 2009. Important Diseases in Cocoa Plants. Politeknik Negeri Lampung. (in Bahasa).

[11] Sukman Y, and Yakub. 2002. Weed and Control Techniques. PT Raja Grafindo Persada, Jakarta pp. 13-15 of 123 pp. (in Bahasa).

[12] Suhendi. 2007. Cocoa Cultivation. PT. Agro Media Pustaka: Jakarta. (in Bahasa).

[13] Sukanto, S. 2013. Disease Control. Penebar Swadaya Publisher. Jakarta. (in Bahasa).pp. 154 - 158.

[14] Susanto, F.X., 2010. Cultivated Cocoa Plants Processing Results. Kanisius Publisher, Jogjakarta. (in Bahasa).

[15] Wardojo, S. 1981. Brown Plant Insect Pests. Plantation Research Center. Bogor. (in Bahasa).

[16] Widya, 2008. Cocoa Plants Come from Tropical Rainforest Areas in South America. Jurnal online Agroteknologi, Vol. 1/ 4.

[17] Yulianita, E. 2016. Weed control techniques in plantation crops (Cocoa). Faculty of Agriculture, Padjadjaran University. (in Bahasa).

*Corresponding author.

E-mail address: ekamartini@gmail.com/widnyanaketut@gmail.com/decksuryana@ gmail.com/ javandira11_unmas@yahoo.co.id/yudiarini@unmas.ac.id 